\title{
New risk method to assess tree interaction with structures
}

Florence W. Y. Ko BEng LLB MA MSC DIC MHKIE MICE CEng Senior Geotechnical Engineer, Geotechnical Engineering Office, Civil Engineering and Development Department, Government of Hong Kong Special Administrative Region (HKSAR), Hong Kong (corresponding author: florenceko@cedd.gov.hk)
Jamie R. Standing MSC DIC PhD MICE CEng

Reader in Ground Engineering, Department of Civil and Environmental Engineering, Faculty of Engineering, Imperial College London,

London, UK

Ground and structural responses to presence of trees can be detrimental if their probable interactions are not duly considered. For example, trees growing in swelling/shrinking clays can lead to damage of buildings that are in close proximity. Very often the problem is not identified until appreciable damage has occurred. Guidelines relating to acceptable distances of trees to buildings are available, but these usually require specialist knowledge of trees. Current practices concerning tree protection and the subject of assessing potential structural damage from trees are reviewed and shortcomings are identified. Following this, two new risk methods to assess likelihood of damage to structures are explained. One covers damage occurring from direct growth of tree roots and the other is associated with settlement/heave above shrink/swell clay. Both systems are intended to provide a basis for identifying situations where advice by tree specialists should be sought, ideally in advance of occurrence of damage. The former was tested by field surveys at several locations in and around London and the latter by well-documented case studies. Both demonstrated that the systems have broad applications. This led to the development of a set of recommendations, in the form of an index chart, for planting trees close to structures.

\section{Notation}

$C_{1} \quad$ consequence score that indicates the likely level of damage

$D_{\mathrm{H}} \quad$ depth factor

$E_{\mathrm{H}} \quad$ exposure factor

$H_{1} \quad$ hazard score that indicates the adequacy of space for air, water and food

$\mathrm{HP}_{\mathrm{HC}} \quad$ height-proximity factor

$P_{\mathrm{C}} \quad$ proximity factor

$R_{1} \quad$ risk score for assessing likelihood of physical damage due to unfavourable root growth

$R_{2} \quad$ risk score for assessing likelihood of physical damage due to ground settlement in shrinkable soils

$S_{\mathrm{C}} \quad$ structural factor

$S_{\mathrm{H}} \quad$ species factor

\section{Introduction}

Interaction of trees with man-made structures is complex and may occur as soon as new trees start growing in close proximity to existing man-made structures or vice versa. Long-term interaction may involve fluctuations in soil moisture causing shrinkage or swelling of soil, and ground settlement or heave; or tree roots intruding into man-made structures, causing cracks or irreparable structural damage; or man-made structures bringing about changes to the environment and soil conditions that lead to a gradual deterioration of tree health (Biddle, 1998). Specifically, Costello and Jones (2003) provide a compendium of strategies for reducing infrastructural damage by tree roots.

Ground and structural responses to the presence of trees can be detrimental if their probable interactions are not duly considered. The problem is very often not identified until appreciable damage has occurred. Laws, regulations and guidelines are in place, but these usually require specialist knowledge of trees. This paper reviews current practices concerning the protection of trees and mitigation of potential structural damage from trees, and identifies shortcomings. Following this, two new risk rating systems developed to facilitate the assessment of likelihood of damage to structures are described and explained. This has led to the development of a set of recommendations, in the form of an index chart, for planting trees close to structures. The chart is intended for use by the members of the general public.

\section{Current practices concerning tree protection and mitigation of structural damage from trees}

Statutory laws and regulations have been developed and implemented in the UK to protect existing trees against damage 
of all kinds and to regulate planting of new trees in relation to urban development. An important aspect of law given in UK's Town and Country Planning Act (OPSI, 1990) requires that, except in certain circumstances, "no work shall be carried out which will affect trees over a certain size which are situated in conservation areas'. Six weeks' notice of intent has to be given to the local authority in advance before the work is carried out. Having considered the case, the local authority may issue a tree preservation order, under this Act, to protect the trees. Should there be any breach of the planning conditions relating to tree protection in the course of work, the local authority can serve an 'enforcement notice' and if necessary, this can be followed up by a 'stop notice'. The Forestry Act (OPSI, 1967) requires a felling licence to be obtained for felling of trees with diameter exceeding a certain value or if the aggregate cubic content of the trees so felled exceeds a specified amount. There are other auxiliary laws and regulations to protect species of flora and fauna (e.g. The Conservation (Natural Habitats etc.) Regulations: OPSI, 1994) and man-made structures from damage caused by tree growth relating in particular to ground movement due to swelling, shrinkage or freezing of the subsoil (Building Regulation: OPSI, 2000). Should any of these forms of legal protection be breached, substantial penalties can be imposed. Apart from statutory provisions, undesirable interaction of trees with man-made structures affecting third parties can result in disputes concerning damage or nuisances caused, giving rise to civil claims and litigation under the common law.

While statutory provisions set out a legal framework for protection of trees and structures, these statutory laws and regulations usually do not elaborate on how the legal requirements can be complied with. Therefore, due to a lack of knowledge and legal support, practitioners in industry often find themselves in a state of confusion as to how to deal with trees and man-made structures in a professional and legitimate manner. In light of this, guidelines (e.g. BSI, 2005; NHBC, 2008; NJUG, 2007; ODPM, 2005) have been published in recent years by the joint efforts of various stakeholders, usually project clients, landscape planners, arborists, engineers and contractors, to assist those involved in this field to form reasonable and informed decisions.

\section{Shortcomings in common practices}

Practitioners in this field may study the laws and regulations related to tree damage and protection and make use of the references and guidelines to assess if physical damage to manmade structures is likely to occur. The references and guidelines, while useful to professionals and specialists working in this area, are however not presented in layman's terms and non-specialist individuals - for example, landowners or estate management agents might find these difficult to understand and follow-up.
The knowledge of trees and their interaction with man-made structures is at present very restrictive. While many trees are located in public places managed by local authorities, there are still large proportions falling within the boundary of private lots owned by management agencies or individual members of the general public. They are legally liable for damage or injury caused by trees on their land and have a duty of care to prevent any foreseeable harm posed to third parties. They should take reasonable steps to assess trees within their land regularly and to manage these in a manner such that potential tree risk likely to cause harm or injury is kept at an as low as reasonably practicable level. However, this liability can, at the present time, at best be discharged by seeking professional advice from any of the qualified tree management agencies available to the public. This is often easier said than done for an average household for two reasons. First, the scale of work involved may be too small for a tree management agency to reap benefits of economy of scale. It would likely to be difficult to obtain a favourable agreement from a qualified tree management agency to take care of only a handful of trees. Second, the cost incurred in a single investigation might not be reasonably affordable.

To bridge this gap, information in relation to diagnosis of interaction of trees with man-made structures should be made more accessible to the general public. The potential capability of the general public to contribute to a pleasant environment for the co-existence of trees and human beings should not be underestimated. As Biddle (1998) commented, it is only with a wide spread of knowledge across different levels in the hierarchy of the population that the prevention of damage from occurring in the first place is possible.

\section{Proposed risk rating systems}

\subsection{Physical damage due to unfavourable root growth}

\subsubsection{Tree/structure survey form}

On the basis of review, together with field observations from a number of locations in London (Figure 1), Windsor and Cambridge, UK, a tree/structure survey form (Appendix 1) is developed to collate key tree/structure information for assessing the likelihood of tree roots causing physical damage to nearby man-made structures. The key information includes: maximum tree height at mature age; maximum canopy diameter at mature age; maximum trunk diameter at $1.5 \mathrm{~m}$ above ground level at mature age; planting conditions - that is, in pits/trenches with soil exposed to air or in pits/trenches with soil covered by hard surface; area of soil exposed; extent of hard surface coverage; depth of pits/trenches; base clearance to structure(s); and physiological condition.

Definition of the terms above and guidelines for data collection are given at the back of the tree/structure survey form itself 


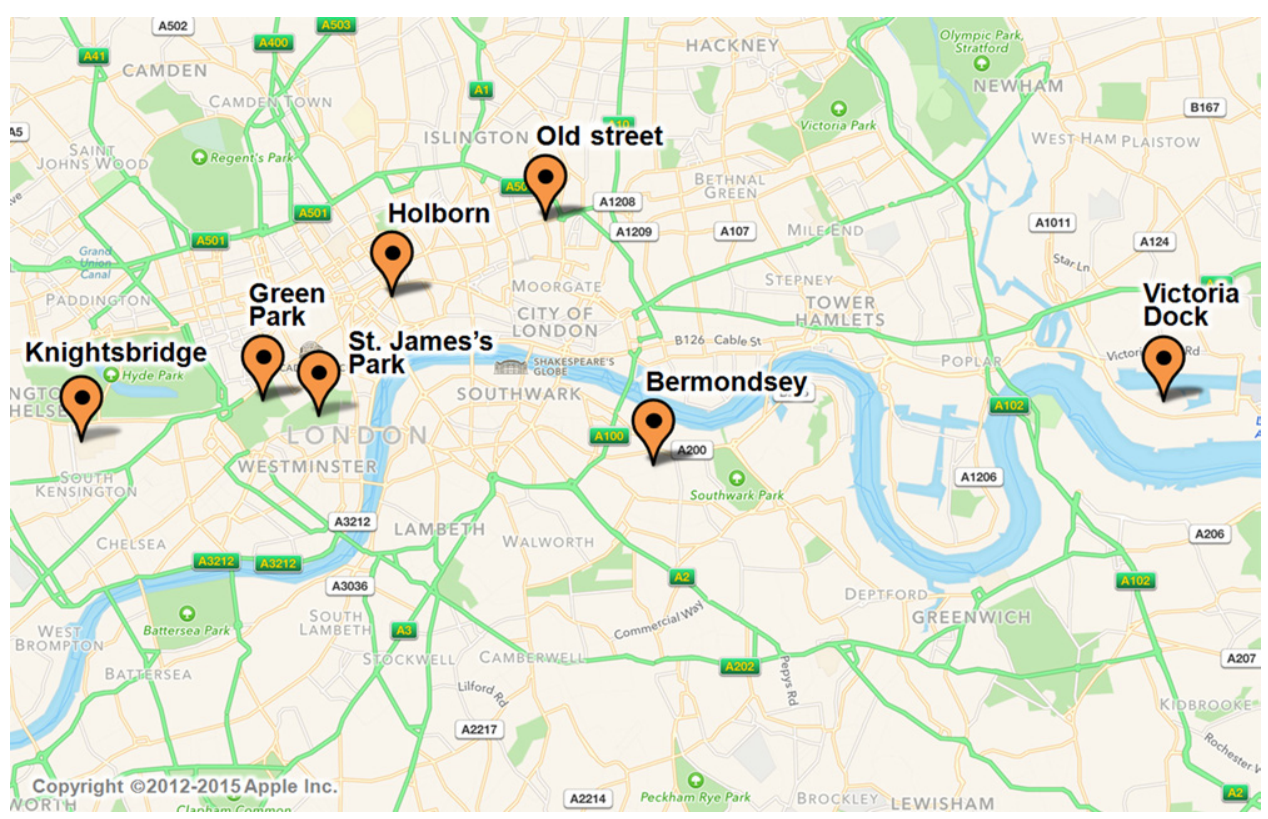

Figure 1. Map showing locations of field observations in

London, UK

(Appendix 1, Part 1, Sheets 3 and 4). Within the form, there has been a deliberate intention to include only key factual information that can be easily understood and managed by a non-specialist individual. Equally, estimation of the dimensions mentioned above 'at mature age' only needs to be approximate: the groupings given in the form (Sheet 1) have intentionally been set to be very broad. Identification of tree species - which normally is an essential item in tree surveys undertaken by specialist arborists - therefore is an optional item under these circumstances. The approach adopted here assumes that the material features of a tree, such as its physical dimensions, planting conditions and proximity to structures, are the fundamental causal factors resulting in physical damage to man-made structures.

Four ranges of values across the possible bandwidth of data for each of the items are adopted in Sheet 1 of the form (Appendix 1, Part 1). The idea of collecting exact and absolute figures for each of the items is in this case not necessary (and difficult to quantify realistically). While it is a good practice to keep a survey form as informative as possible, one has to bear in mind the limited knowledge and technical skills usually possessed by an average individual as compared with specialist arborists; the purpose of the exercise is to provide a preliminary screening.

\subsubsection{Risk rating system}

The tree information collated is then analysed against a risk rating system. The rating system comprises three major parts: a hazard model, a consequence model and a risk model.

\subsubsection{HAZARD MODEL}

The hazard model examines the adequacy of surface area and depth of breathable soil for a given tree to acquire air, water and food. The adequacy of this space directly affects proper root growth. Unfavourable root growth would be highly likely to result in physical damage to nearby man-made structures.

Trees are first categorised into four hazard groups according to their maximum canopy diameter and trunk diameter at mature height (Appendix 1, Part 2, Sheet 1, Item A). Tree growth is a complex subject. There is no definite rule governing the growth behaviour of trees and the final outcome, such as root shape and extent, is always unpredictable, even for the same tree species, unless these are grown under strictly controlled conditions. It is, however, believed that trees with comparable physical dimensions would have similar demands for space that is necessary both for growth and food collection. As such, grouping trees of comparable sizes for analysis in this case is assumed to be both sensible and reasonable; canopy diameter and trunk diameter are two basic tree features that are the most representative of the physical tree dimensions.

Each tree is then rated by two factors, the exposure factor $\left(E_{\mathrm{H}}\right)$ and the depth factor $\left(D_{\mathrm{H}}\right)$, according to the hazard group it belongs to. The exposure factor accounts for the adequacy of an exposed soil area for air, water and food while the depth factor looks into the adequacy of the soil depth for proper root growth. 
Each hazard component - that is, $E_{\mathrm{H}}$ and $D_{\mathrm{H}}$, is assessed through a $4 \times 4$ hazard matrix (Appendix 1, Part 2, Sheet 1, Items B and C). A sliding scale of four ratings - that is, 1, 3, 6 and 10, is adopted to represent the scale of significance. Rating ' 1 ' represents the most satisfactory condition, while ' 10 ' the least. A logarithmic scale is chosen to give a sufficiently wide range of risk scores so that a realistic classification of cases is possible. A summation of the two factors gives the hazard score $\left(H_{1}\right)$ for a given tree that indicates the adequacy of space for air, water and food

1. $H_{1}=E_{\mathrm{H}}+D_{\mathrm{H}}$

\subsubsection{CONSEQUENCE MODEL}

The consequence model examines the likelihood of damage that a given hazard scenario - that is, unfavourable root growth in this case, may bring to nearby man-made structures.

Given the applied pressure by tree roots, the impact on manmade structures of different forms may vary. Light structures or those with negligible lateral restraint - for example, hard surfacing or paving, are the most vulnerable to displacement and damage. A more substantial structure or one with lateral restraint is more likely to resist the forces that tree roots can usually generate. The likely resistance as provided by various forms of structures should, therefore, be duly taken into account in the consequence model.

Biddle (1998) suggests that the closer the roots are to the tree trunk, the greater the exerting pressure these possess. As such, man-made structures that are close to the tree trunk would be subject to greater risk of physical damage caused by growing tree roots. The proximity of man-made structures to the tree trunk is, therefore, another crucial factor to be considered in the consequence model.

The likely resistance of structures of different forms to a given applied pressure from tree roots and their proximity to the tree trunk is expressed by the structural factor $\left(S_{\mathrm{C}}\right)$ and the proximity factor $\left(P_{\mathrm{C}}\right)$, respectively. The former is assessed by way of a $4 \times 1$ consequence matrix while for the latter it is through a $4 \times 4$ consequence matrix (Appendix 1, Part 2, Sheet 2, Items D and E). The same sliding scale of four ratings - that is, 1, 3, 6 and 10, is adopted to represent the scale of significance. A summation of the two factors gives the consequence score $\left(C_{1}\right)$ for a given tree that indicates the likely level of damage caused by the corresponding hazard scenario

2. $C_{1}=S_{\mathrm{C}}+P_{\mathrm{C}}$

\subsubsection{RISK MODEL}

The risk model combines the hazard model and the consequence model to calculate the risk of a given tree causing possible physical damage to nearby man-made structures.

Assuming that the two hazard components and the two consequence components have equal weighting, the risk score $\left(R_{1}\right)$ is the mathematical sum of the four components

3. $R_{1}=H_{1}+C_{1}=\left(E_{\mathrm{H}}+D_{\mathrm{H}}\right)+\left(S_{\mathrm{C}}+P_{\mathrm{C}}\right)$

The risk score so obtained has a minimum value of 4 (i.e. exposure factor, $E_{\mathrm{H}}=1$; depth factor, $D_{\mathrm{H}}=1$; structural factor, $S_{\mathrm{C}}=1$; proximity factor, $P_{\mathrm{C}}=1$ ) and a maximum value of 40 (i.e. $E_{\mathrm{H}}=10 ; D_{\mathrm{H}}=10 ; S_{\mathrm{C}}=10 ; P_{\mathrm{C}}=10$ ). It can be readily deduced that the lower the score, the less the likelihood of an adverse interaction of trees with man-made structures. For screening purposes, four risk classifications that specify the relative likelihood of adverse interaction of trees with manmade structures are defined (Table 1 and Appendix 1, Part 2, Sheet 3, Item G).

\subsection{Physical damage due to ground settlement in shrinkable soils}

Cutler and Richardson (1989) document abundant data collected in the Kew Tree Root Survey (1971-1979) and supplementary information concerning the spread of roots from trees reported as having caused or contributed to damage to buildings. This provides a valuable source of information for a systematic diagnosis of the interaction of different tree species, particularly in clay soils, with buildings.

\begin{tabular}{|c|c|c|}
\hline Risk score & $\begin{array}{l}\text { Risk } \\
\text { classification }\end{array}$ & Description \\
\hline$<10$ & VERY UNLIKELY & $\begin{array}{l}\text { Adverse interaction of trees with } \\
\text { man-made structures is } \\
\text { VERY UNLIKELY }\end{array}$ \\
\hline 10 to $<20$ & UNLIKELY & $\begin{array}{l}\text { Adverse interaction of trees with } \\
\text { man-made structures is } \\
\text { UNLIKELY }\end{array}$ \\
\hline 20 to $<30$ & LIKELY & $\begin{array}{l}\text { Adverse interaction of trees with } \\
\text { man-made structures is LIKELY }\end{array}$ \\
\hline $30-40$ & VERY LIKELY & $\begin{array}{l}\text { Adverse interaction of trees with } \\
\text { man-made structures is } \\
\text { VERY LIKELY }\end{array}$ \\
\hline
\end{tabular}

Table 1. Risk classification for cases of physical damage due to unfavourable root growth 
The tree data collated are summarised into a series of standardised, detailed and concise tree entries for 16 different tree species, which are found to be commonly associated with building damage in clay soils in the UK. The authors, however, did not synthesise various essential data to see if a global trend of behaviour can be observed, in particular, for the correlation of likelihood of damage with tree height and distance to the point of concern. An understanding of this relationship would help to develop a risk assessment framework for assessing the likelihood of hazard and damage a given tree may bring to a building. Therefore, the opportunity is taken here to investigate this proposition.

\subsubsection{Hazard mode}

From the data collated by Cutler and Richardson (1989), it can be deduced that tree species and tree height are two key hazard elements for trees in shrinkable clay soils that could result in building damage. On this basis, the hazard model given in Appendix 2 is therefore proposed, involving a species factor and a height factor (in reality this is simply the tree height as defined in Appendix 1, Part 1, Sheet 3, Item 2).

The hazard module for determining the species factor $\left(S_{\mathrm{H}}\right)$ is formulated based on the observations discussed in Cutler and Richardson (1989). Cutler and Richardson (1989) identified tree species for which the proportion of trees reported to have caused damage to buildings is high and those for which the proportion is low. Given this coarse classification, only a hazard module of two ratings can be developed - that is, ' 1 ' for tree species with a high proportion of trees reported to have caused damage to buildings and ' 0 ' for those with a low proportion of building damage.

The hazard module for determining the height factor is combined with the consequence module for determining the proximity factor to give a combined height-proximity factor $\left(\mathrm{HP}_{\mathrm{HC}}\right)$ since the two factors are strongly interrelated, as discussed below in the section on the consequence model.

\subsubsection{Consequence model}

The same considerations taken in developing the consequence model in Section 4.1.2 apply here as well (Appendix 1, Part 2, Sheet 2). The likely resistance of structures of different forms to a given amount of ground subsidence and their proximity to the tree trunk are two key causal factors leading to building damage and are expressed using the structural factor and the proximity factor, respectively.

The same module for determining the structural factor $\left(S_{\mathrm{C}}\right)$, as explained in Section 4.1.2.2, is used. A separate consequence matrix for determining the proximity factor is, however, required as a different nature of consequence is being examined (i.e. shrinkable clay soils causing ground subsidence and consequently structural damage, which is different from tree roots causing physical damage to structures). The data collated by Cutler and Richardson (1989) are plotted in the form of maximum distance to the point of damage as against maximum tree height in Figure 2. Sixteen species of trees are considered and the maximum height refers to the maximum height to which that tree type can grow - for example, the two species with the greatest maximum height are poplar and plane at 28 and $30 \mathrm{~m}$, respectively. Cutler and Richardson (1989) collated data for each species in the form of the percentage of cases where damage occurred against the distance to the point of damage. These percentages can be cumulated and related to distance to the point of damage as shown in Table 2 for the poplar and plane tree cases. In Figure 2, for each species the distance to the point of damage for four cumulative percentages are plotted (50, 75, 90 and 100\%). In the case of the poplar tree, for example, no damage was observed when the tree was more than $30 \mathrm{~m}$ from the structure $(100 \%)$; only $10 \%$ of cases of damage were observed when the tree was more than $20 \mathrm{~m}$ from the point of interest $(90 \%)$ and so on. The lowest cumulative percentage considered and shown is $50 \%$ as beyond this level the distances are frequently relatively small and so there is greater uncertainty in accurately assessing whether the tree might cause damage. Figure 2 shows a clear correlation of likelihood of damage to buildings with maximum tree height and the distance to the point of damage. It is clear that the likelihood of damage increases with tree height (as shown by an increasing influence of distance as tree height increases), but decreases with increasing distance to the point of concern (as indicated by a reducing percentage of cases as distance to damage increases). Given this correlation, it is considered reasonable to combine the consequence matrix for determining the proximity factor, $P_{\mathrm{C}}$, with the hazard module for determining the height factor to give the combined height-proximity factor $\left(\mathrm{HP}_{\mathrm{HC}}\right)$. The ratings are defined by the four bands of likelihood of damage, as shown in Figure 3, which indicate the scale of significance.

In view of the above finding, the following comments by Cutler and Richardson (1989) might be reconsidered: 'It is less clear how height and potential for root damage to buildings are related. For example, vigorous, semi-mature trees with a very active root system may be drawing on water from the soil more effectively and in greater quantities than taller, old trees well past their prime'. The correlation is certainly representative as it is derived based on the data collated from several thousand tree samples in shrinkable clay soils which are commonly associated with building damage. It is, therefore, a good reference for assessing likelihood of damage to buildings by trees at a mature age. Having this as a basis, 


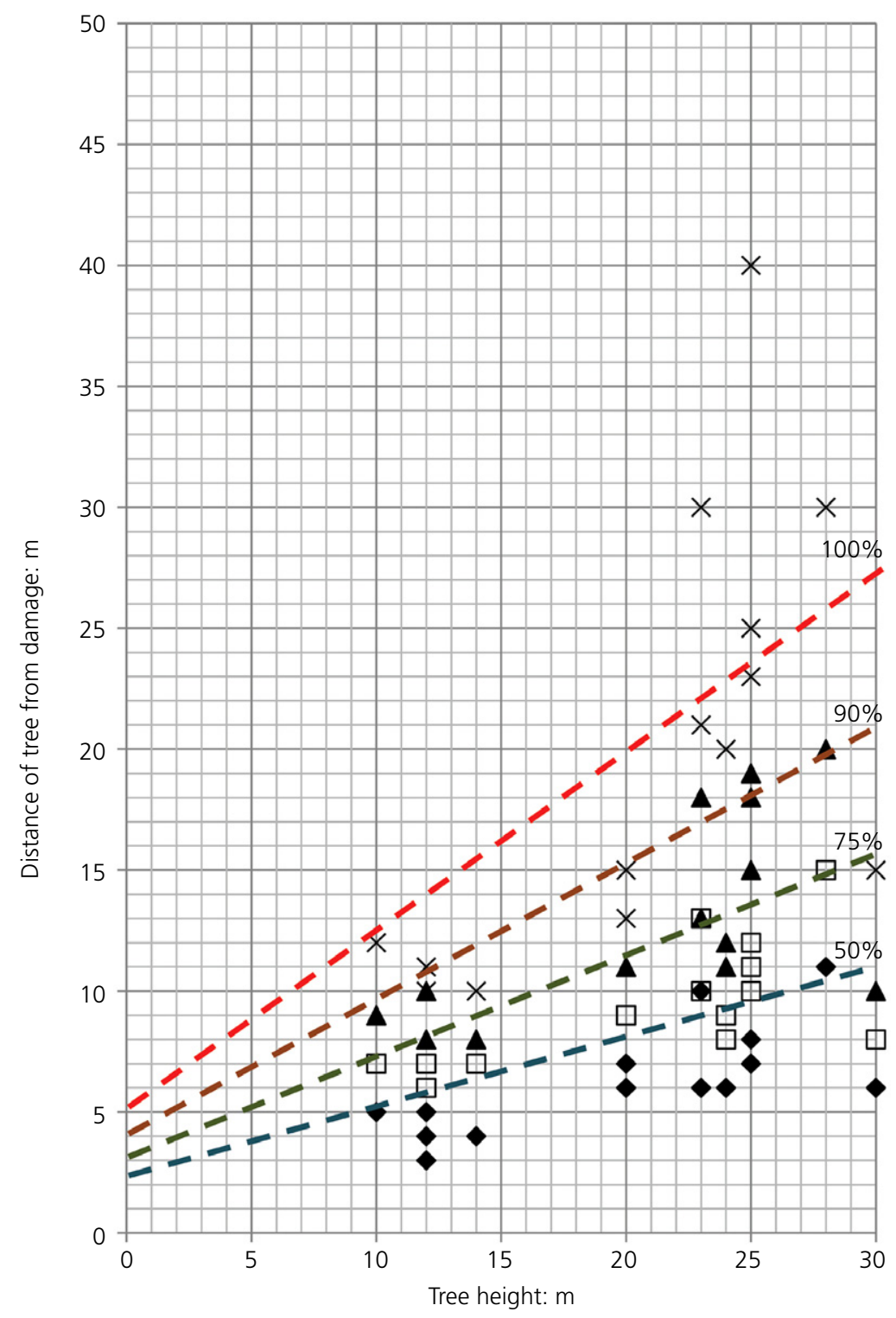

Cumulative percentage of individual species:

Note: Distance of tree from damage is the shortest distance measured between the tree trunk of the tree that causes damage and the most obvious damage on the structure. The data shown are the maximum values obtained for the individual species.

Figure 2. Correlation of likelihood of damage with tree height and distance of tree from the potential location of damage

an adjustment module may be included to take into account the fact that demand for water may vary with tree age. By applying risk management techniques and principles, height and potential for root damage to buildings can certainly be related.

\subsubsection{Risk model}

The risk model combines the hazard model and the consequence model to calculate the risk of a given tree in shrinkable clay soils causing possible damage to nearby man-made structures due to ground subsidence. 
Municipal Engineer

Volume 170 Issue ME1
New risk method to assess tree

interaction with structures

Ko and Standing

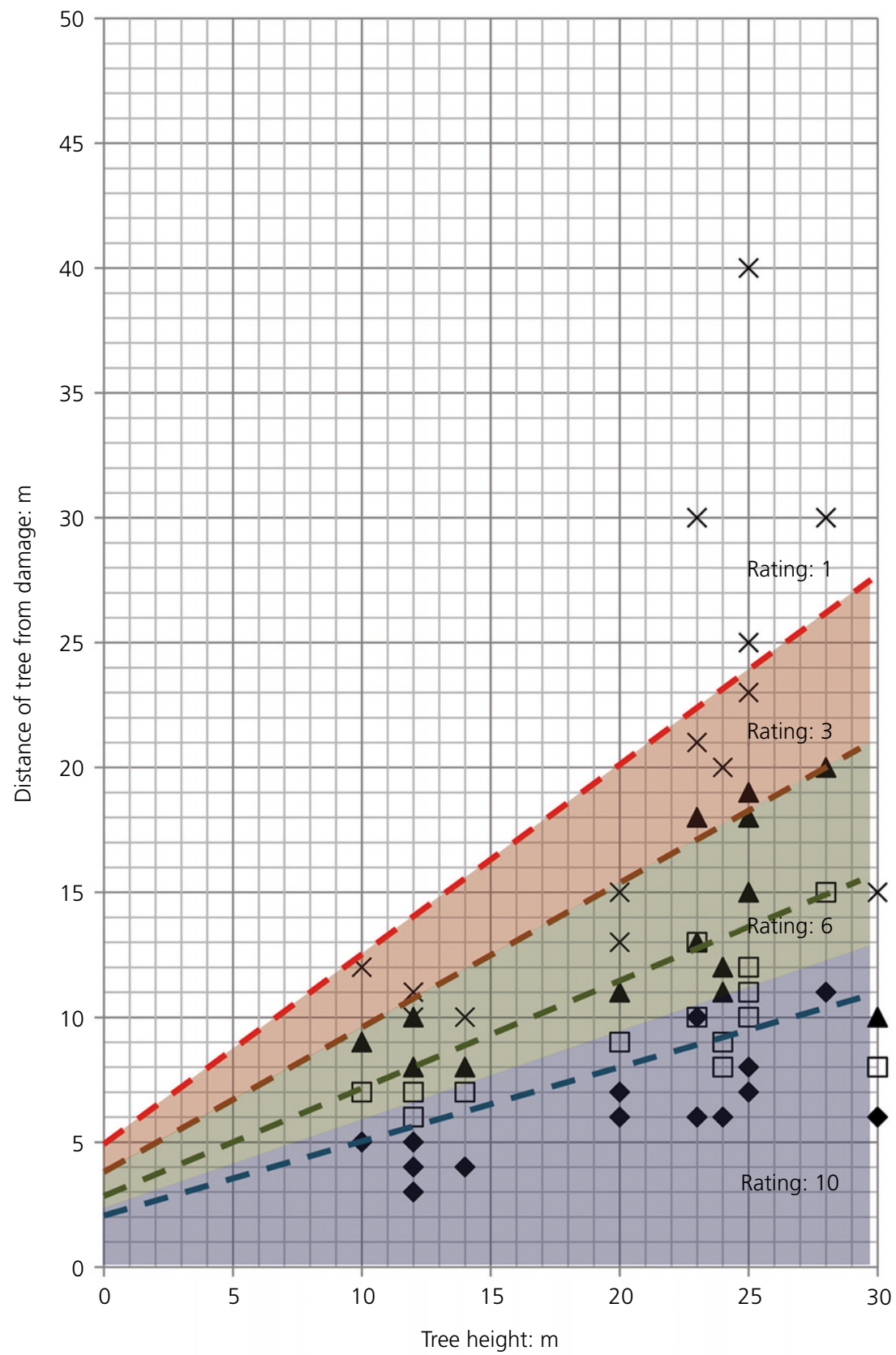

Cumulative percentage of $\quad 50 \% \quad \square 75 \% \quad \Delta 90 \% \quad \times 100 \%$ individual species:

Note: Distance of tree from damage is the shortest distance measured between the tree trunk of the tree that causes damage and the most obvious damage on the structure. The data shown are the maximum value obtained for the individual species.

Figure 3. Height-proximity ratings 


\begin{tabular}{lcc}
$\begin{array}{l}\text { Cases of } \\
\text { damage: } \%\end{array}$ & $\begin{array}{c}\text { Cumulative cases of } \\
\text { damage: } \%\end{array}$ & $\begin{array}{c}\text { Maximum distance } \\
\text { from damage: } \mathrm{m}\end{array}$ \\
\hline $\begin{array}{l}\text { (a) Poplar (maximum tree height }=28 \mathrm{~m} \text { ) } \\
0\end{array}$ & 100 & $>30$ \\
10 & 100 & 30 \\
15 & 90 & 20 \\
25 & 75 & 15 \\
25 & 50 & 11 \\
25 & 25 & 7 \\
(b) Plane (maximum tree height=30 m) & $>15$ \\
0 & 100 & 15 \\
10 & 100 & 10 \\
15 & 90 & 8 \\
25 & 75 & 6 \\
25 & 50 & \\
25 & 25 & \\
Table 2. Example of data on proportion of cases of damage \\
occurring within certain bands of distance from the tree species \\
on shrinkable clay soils \\
\hline
\end{tabular}

Assuming that the hazard and consequence components have equal weighting, the risk score $\left(R_{2}\right)$ is equal to

4. $R_{2}=S_{\mathrm{H}} \times\left(S_{\mathrm{c}}+\mathrm{HP}_{\mathrm{HC}}\right)$

The risk score so obtained has a minimum value of 0 (i.e. species factor, $S_{\mathrm{H}}=0$ ) and a maximum value of 20 (i.e. $S_{\mathrm{H}}=1$; structural factor, $S_{\mathrm{C}}=10$; height-proximity factor, $\mathrm{HP}_{\mathrm{HC}}=10$ ). Similarly, the lower the score, the less likely there will be an adverse interaction of trees with man-made structures. As in Section 4.1.2.3, four risk classifications that specify the relative likelihood of adverse interaction of trees with man-made structures are defined (Table 3 and Appendix 2, Part 1, Sheet 2, Item E).

\section{Calibration}

\subsection{Physical damage due to unfavourable root growth}

As each problem has its own particular characteristics, it is prudent to calibrate the models so as to test out the assumptions made, particularly the reasonableness of the sliding scale and the risk classifications adopted in this case. The calibration is done in two ways: (a) field calibration and $(b)$ calibration with the BRE (1995) category of damage (Burland, 1995).

\subsubsection{Field calibration}

The tree/structure survey form and the hazard, consequence and risk models were put to test in the field. A total of 30 trees randomly selected from a number of places in London, Windsor and Cambridge, UK, were surveyed in July 2009. The locations of the fieldwork in London are shown in Figure 1.

\begin{tabular}{|c|c|c|}
\hline Risk score & Risk classification & Description \\
\hline$<5$ & VERY UNLIKELY & $\begin{array}{l}\text { Adverse interaction of trees } \\
\text { with man-made structures is } \\
\text { VERY UNLIKELY }\end{array}$ \\
\hline 5 to $<10$ & UNLIKELY & $\begin{array}{l}\text { Adverse interaction of trees } \\
\text { with man-made structures is } \\
\text { UNLIKELY }\end{array}$ \\
\hline 10 to $<15$ & LIKELY & $\begin{array}{l}\text { Adverse interaction of trees } \\
\text { with man-made structures is } \\
\text { LIKELY }\end{array}$ \\
\hline $15-20$ & VERY LIKELY & $\begin{array}{l}\text { Adverse interaction of trees } \\
\text { with man-made structures is } \\
\text { VERY LIKELY }\end{array}$ \\
\hline
\end{tabular}

Table 3. Risk classification for cases of physical damage due to ground settlement in shrinkable soils

\begin{tabular}{|c|c|c|c|c|c|}
\hline & \multicolumn{4}{|c|}{ Tree group } & \multirow[b]{2}{*}{ Tota } \\
\hline & Group 1 & Group 2 & Group 3 & Group 4 & \\
\hline \multicolumn{6}{|l|}{ Exposure condition } \\
\hline Soil cover & 0 & 13 & 8 & 4 & 25 \\
\hline Hard surfacing & & 2 & 3 & 0 & 5 \\
\hline Total & 0 & 15 & 11 & 4 & 30 \\
\hline \multicolumn{6}{|l|}{ Structures affected } \\
\hline $\begin{array}{l}\text { Pavement and } \\
\text { other man-made } \\
\text { structures }\end{array}$ & 0 & 5 & 3 & 4 & 12 \\
\hline Pavement only & 0 & 5 & 5 & 0 & 10 \\
\hline $\begin{array}{l}\text { Other man-made } \\
\text { structures only }\end{array}$ & 0 & 5 & 3 & 0 & 8 \\
\hline Total & 0 & 15 & 11 & 4 & 30 \\
\hline
\end{tabular}

Table 4. Summary of key tree information from the tree survey

Only one sample each at Windsor and Cambridge was taken and therefore their locations are not indicated in Figure 1. The following summarises the key tree information.

- No trees belong to group 1, 15 trees $(50 \%)$ to group 2, 11 trees $(37 \%)$ to groups 3 and 4 trees $(13 \%)$ to group 4 (Appendix 1, Part 2, Sheet 1 for quantification of groups).

- Twenty-five trees $(83 \%)$ have soil cover while five trees $(17 \%)$ are covered by hard surface. Their distribution within each tree group is shown in Table 4.

- Twelve trees (40\%) affect both pavement and man-made structures, ten trees $(33 \%)$ affect pavement only while 8 trees $(27 \%)$ affect man-made structures only. Their distribution within each tree group is shown in Table 4. 
Key observations from the field calibration are discussed below.

Man-made structure - pavement.

- There are in total 22 trees affecting pavements.

- Of the 11 trees exhibiting obvious destructive behaviour that is, with tree roots causing physical damage to pavements, $100 \%$ of these have a risk score ranging between 20 and 40. All fall into the risk class of 'LIKELY' or 'VERY LIKELY', which means adverse interaction of trees with man-made structures is 'likely' and 'very likely'. The risk scores match well with the field observations.

- Of the 11 trees without obvious destructive behaviourthat is, tree roots causing physical damage to pavements have not been observed, about $90 \%$ of these (i.e. 10 trees) have a risk score ranging between 4 and $<20$. They fall into the risk class of 'UNLIKELY' or 'VERY UNLIKELY', which means adverse interaction of trees with man-made structures is 'unlikely' and 'very unlikely'. The risk scores match well with the field observations.

- There is, however, one case that has a risk score of 20, which falls marginally into the risk class of 'LIKELY', but no obvious destructive behaviour has been observed. The risk assessment framework identifies it as a case in which obvious destructive behaviour should have occurred, as there is not sufficient space for root growth with respect to the tree size and the pavement is too close to the tree trunk. The discrepancy between the risk assessment result and the field observation may be due to the fact that the expected destructive behaviour may have yet to appear or may have occurred and been repaired. For either case, it is recommended that in order to avoid physical damage to the pavement, the exposed soil area of the tree should be enlarged to $>1.0 \times 1.0 \mathrm{~m}^{2}$. The risk scores would then fall to 18 and into the risk classification of 'UNLIKELY'.

Man-made structure - other structures.

- There are in total 18 trees affecting man-made structures other than pavements.

- Of the ten trees with obvious destructive behaviour that is, with tree roots causing physical damage to other structures - for example, brick wall and planter, $100 \%$ of these have risk score ranging between 20 and 30 . All fall into the risk class of 'LIKELY', which means adverse interaction of trees with man-made structures is likely. The risk scores match well with the field observations.

- Of the eight trees without obvious destructive behaviour - that is, tree roots causing physical damage to other structures have not been observed, $100 \%$ of these have risk score ranging between 6 and 19. They fall into the risk class of 'UNLIKELY' or 'VERY UNLIKELY', which means adverse interaction of trees with manmade structures is 'unlikely' and 'very unlikely'. The risk scores match well with the field observations.

\begin{tabular}{lccc}
$\begin{array}{l}\text { Tree } \\
\text { number }\end{array}$ & $\begin{array}{c}\text { Measured crack } \\
\text { width: mm }\end{array}$ & $\begin{array}{c}\text { Category of } \\
\text { damage }\end{array}$ & $\begin{array}{c}\text { Risk } \\
\text { score }\end{array}$ \\
\hline 17-BM05 & 3 & 2 & 20 \\
18-BM06 & 1 & 1 & 20 \\
13-BM01 & 6 & 3 & 26 \\
19-BM07 & 7 & 3 & 26 \\
22-W01 & 10 & 3 & 27
\end{tabular}

(Note: BM and W denote Bermondsey and Windsor, respectively)

Table 5. Risk scores against the BRE (1995) category of damage

\subsubsection{Calibration with the BRE category of damage}

The models and the risk classification can also be calibrated with the BRE (1995) category of damage (Burland, 1995) for cases involving physical damage to walls using field measurement of crack width (Table 5) as a primary factor, while taking into account other relevant observations. Key observations are discussed below.

- The models and the risk classification give results that are comparable with the BRE (1995) category of damage and correctly differentiate cases with and without physical damage to walls.

- All cases in the risk class of 'LIKELY' have the BRE category of damage of at least ' 1 - VERY SLIGHT'. Other cases in the risk class of 'VERY UNLIKELY' or 'UNLIKELY' have the BRE category of damage of ' 0 - NEGLIGIBLE'.

- The risk score increases with the severity of damage as exemplified in the crack width measured.

- Marginal cases in the risk class of 'LIKELY' with score around 20 are observed to link with the category of damage of ' 1 - VERY SLIGHT' and ' 2 - SLIGHT'. Cases with higher risk score in the risk class of 'LIKELY' correspond to the ' 3 - MODERATE' category of damage.

- It is predicted that cases in the risk class of 'VERY LIKELY' would match up with the ' 4 - SEVERE' and '5 - VERY SEVERE' categories of damage.

\subsection{Physical damage due to ground settlement in shrinkable soils}

No fieldwork was carried out for this case due to the scope of the project, but four case studies documented in Biddle (1998) are reviewed and used as test cases for model calibration. Key information is summarised in Table 6.

The findings indicate that all cases with building damage caused by ground settlement in shrinkable clay soils have risk scores above 10 - that is, adverse interaction of trees with manmade structures is either 'LIKELY' or 'VERY LIKELY' (Appendix 2, Part 1, Sheet 2, Item E). The risk scores match well with the field observations. 
Municipal Engineer

Volume 170 Issue ME1
New risk method to assess tree

interaction with structures

Ko and Standing

\begin{tabular}{llcrr}
$\begin{array}{l}\text { Case study } \\
\text { number }\end{array}$ & Tree species & $\begin{array}{c}\text { Average tree } \\
\text { height: } \mathrm{m}\end{array}$ & Type of structures affected & $\begin{array}{r}\text { Average distance } \\
\text { to damage: } \mathrm{m}\end{array}$ \\
\hline 5 & Poplar & $23 \cdot 5$ & Brick partition walls & $12 \cdot 5$ \\
6 & Horse chestnut and oak & $14 \cdot 5$ & Brick flank and partition walls & $6 \cdot 5$ \\
7 & Oak & $21 \cdot 0$ & Brick flank and partition walls & $13 \cdot 0$ \\
8 & Lime & $20 \cdot 0$ & Brick flank and partition walls & $5 \cdot 5$
\end{tabular}

Table 6. Key information from case studies for model calibration

(Biddle, 1998)

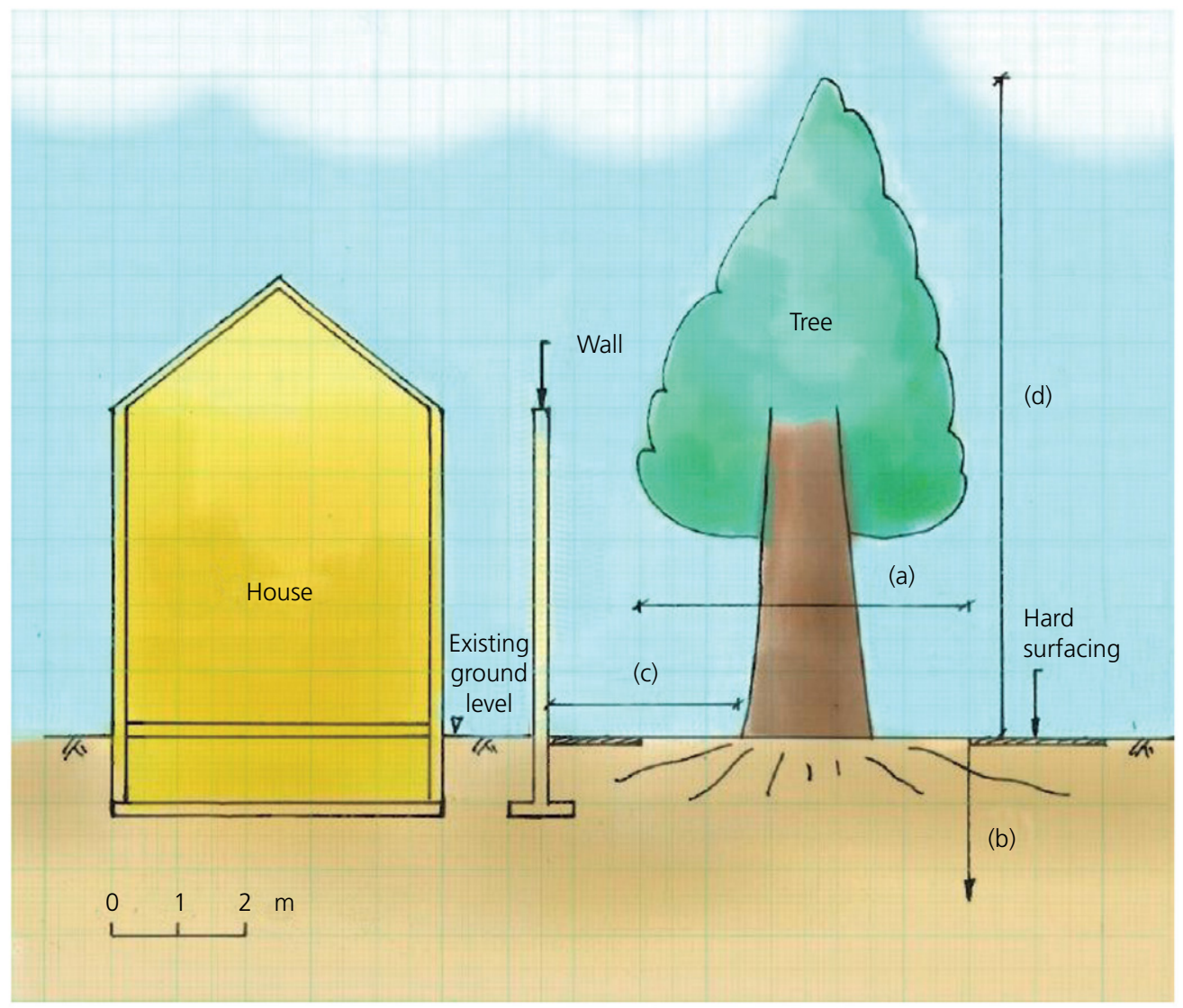

(a) Tree group chart

\begin{tabular}{lcccccc}
\cline { 3 - 6 } & & \multicolumn{4}{c}{ Maximum actual/estimated stem diameter: $\mathrm{mm}$} \\
\cline { 2 - 6 } & & $<150$ & $\mathrm{G} 150$ to $<300$ & 300 to $<600$ & 2600 \\
\hline \multirow{2}{*}{$\begin{array}{l}\text { Maximum } \\
\text { actual/estimated } \\
\text { canopy diameter: } \mathrm{m}\end{array}$} & 2 to $<4$ & $\mathrm{G} 1$ & $\mathrm{G} 1$ & $\mathrm{G} 2$ & $\mathrm{G} 2$ \\
\cline { 2 - 7 } & 4 to $<8$ & $\mathrm{G} 2$ & $\mathrm{G} 2$ & $\mathrm{G} 2$ & $\mathrm{G} 3$ \\
\cline { 2 - 6 } & $\geq 8$ & $\mathrm{G} 2$ & $\mathrm{G} 3$ & $\mathrm{G} 3$ & $\mathrm{G} 3$ \\
\hline
\end{tabular}

Figure 4. Tree planting index chart: (a) tree group chart;

(b) planting chart (1); (c) planting chart (2) 
(b) Planting chart (1)

- to avoid physical damage directly caused by root growth

\begin{tabular}{|c|c|c|c|c|c|c|}
\hline \multirow[t]{2}{*}{$\begin{array}{l}\text { Tree } \\
\text { group }\end{array}$} & \multirow[t]{2}{*}{$\begin{array}{l}\text { (a) } \\
\text { Exposed soil } \\
\text { area: } \\
\mathrm{m}^{2}\end{array}$} & \multirow[t]{2}{*}{$\begin{array}{l}\text { (b) } \\
\text { Depth of suitable } \\
\text { planting soils: } \\
\text { m }\end{array}$} & \multicolumn{4}{|c|}{$\begin{array}{c}(\mathrm{c}) \\
\text { Proximity to structures other than } \\
\text { pavements: } \\
\mathrm{m}\end{array}$} \\
\hline & & & $V L^{*}$ & $L^{*}$ & $S^{*}$ & VS* \\
\hline G1 & $1.0 \times 1.0$ & 1.5 & 1.5 & 1.5 & 1.5 & 1.5 \\
\hline G2 & $1.5 \times 1.5$ & 1.5 & 2.5 & 2.5 & 1.5 & 1.5 \\
\hline G3 & $2.5 \times 2.5$ & $2 \cdot 0$ & $3 \cdot 5$ & $3 \cdot 5$ & $2 \cdot 5$ & 1.5 \\
\hline G4 & $3.5 \times 3.5$ & $2 \cdot 0$ & $3 \cdot 5$ & 3.5 & $2 \cdot 5$ & 1.5 \\
\hline
\end{tabular}

(c) Planting chart (2)

- to avoid physical damage caused by ground settlement in shrinkable clay soils

\begin{tabular}{cc}
\hline Structure type & Planting zone \\
\hline$V L^{*}$ & 1 \\
\hline$L^{*}$ & 2 \\
\hline$S^{*}$ & 3 \\
\hline$V S^{*}$ & 3 \\
\hline
\end{tabular}

Notes:

*VL, very light without lateral restraint structures, e.g. asphalt/brick pavement or low brick wall; L, light without lateral restraint structures, e.g. high brick wall; $\mathrm{S}$, substantial with lateral restraint structures, e.g. concrete parapet wall; VS, very substantial with lateral restraint structures, e.g. concrete building wall

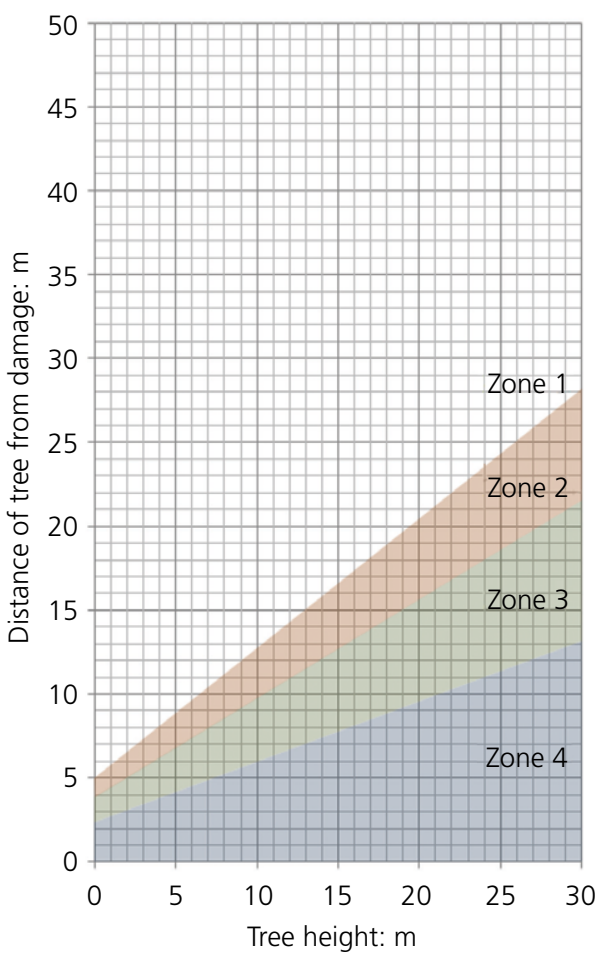

Figure 4. Continued

Despite this, the following limitations of the risk assessment framework should be noted.

- The hazard and consequence models are formulated based on a limited amount of processed tree data that have been taken as the best estimate.

- There was no opportunity to review the raw data. It is not known how the data were processed and any uncertainties involved cannot be reasonably accounted for.

The calibration of the risk assessment modules is not sufficiently rigorous, with only four case studies reviewed. For wider application, the method needs more substantiated validation.

\section{Recommendations}

On the basis of observations from the fieldwork, a set of recommendations with regard to the proper planting of trees of different sizes close to man-made structures has been developed. These are summarised in the tree planting index chart (Figure 4). The diagram provides a good practice guide, in layman's terms and style, to plant a tree of certain size so that potential physical damage to nearby man-made structures is minimised. A member of the public may find it useful when they plan to plant a tree in their front or back garden, or when one would like to have a quick check of the conditions of a tree with regard to its capability to cause physical damage to nearby man-made structures. 


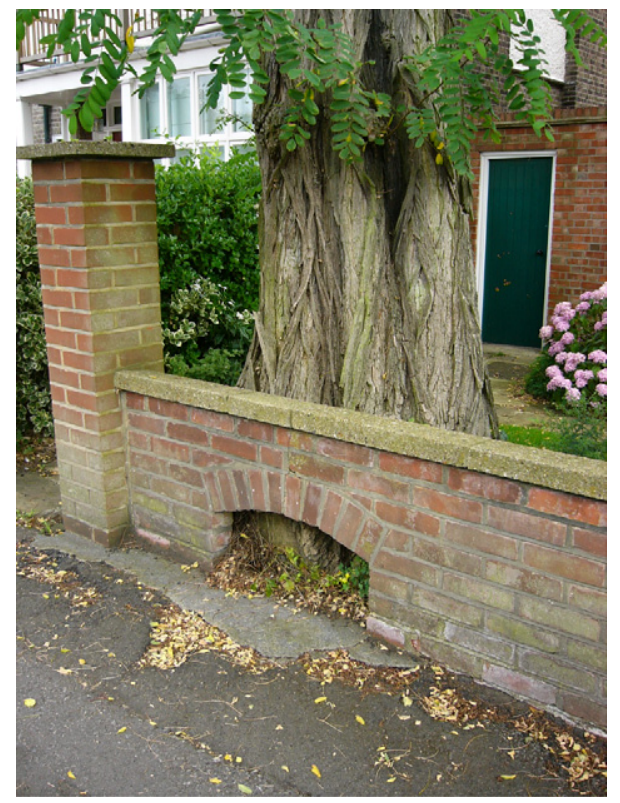

(a)

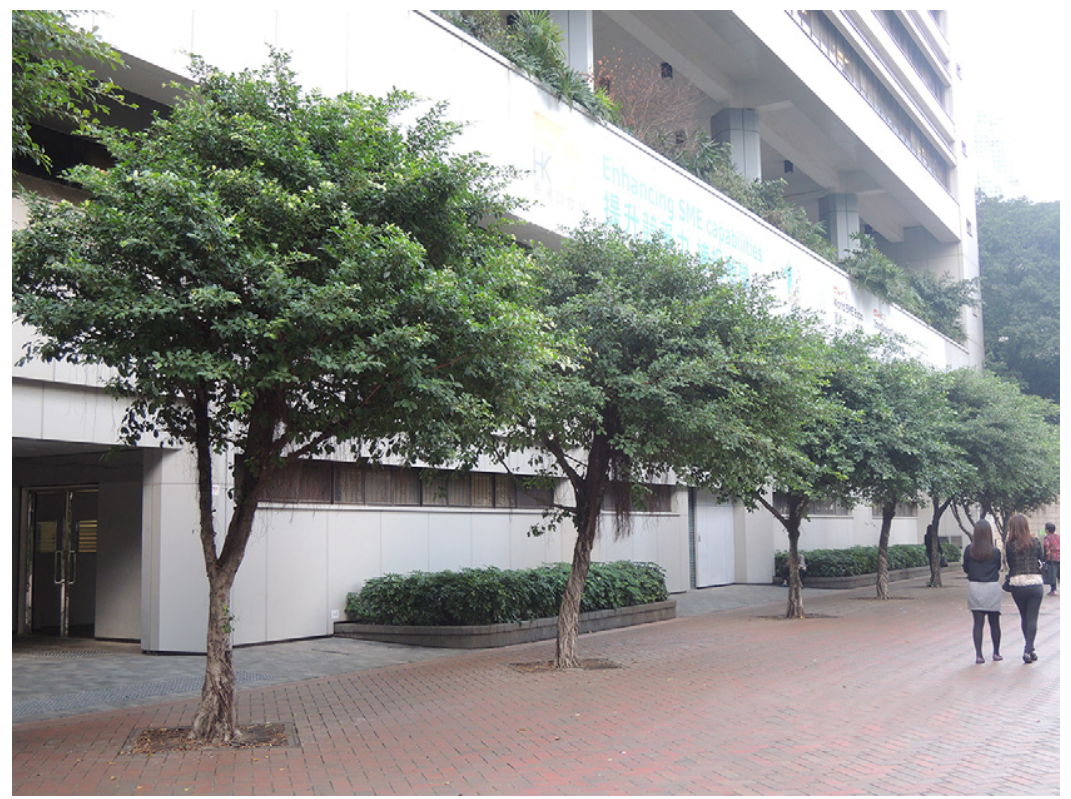

(b)

Figure 5. Innovative ideas for planting trees: (a) case A and

(b) case $B$

Even without the above chart, the general public should be reassured that most of the time, assessing and mitigating damage from trees is somehow intuitive and requires only common sense. Figure 5 shows some innovative ideas of blending environmental development in harmony with trees; this will involve little or no technical/engineering input. With an impartial pursuit of innovative ideas, building a green society along with advanced capital development is achievable.

\section{Conclusions}

Trees are an important asset to the environment and everyone on earth has a duty of care to preserve the healthy growth of trees. However, knowledge and skills of tree protection are generally restricted to a small class of professionals such as arborists, landscape planners, architects, engineers and contractors. The level of understanding of the subject is nonetheless not uniform across different professions. Their communication links are also not active and strong. This often leads to a lack of appreciation of each other's design concerns and requirements, bringing about undesirable consequences to trees and man-made structures.

There is plenty of scope for improvement within this field and the practices involving the protection of trees and assessing potential damage from trees on man-made structures. In particular, wide participation of the general public in the process of tree planting, protection and preservation should be encouraged. Increasing the spread of knowledge across all levels within the population would help prevent damage occurring in the first place.

Two new rating systems for application by the general public to assess the likelihood of physical damage to structures due to direct growth of tree roots and ground settlement in shrinkable clay soils have been developed. These have been deliberately designed to operate on simple measurable tree data so that the trees can be easily managed by members of the general public. It is demonstrated that the rating systems work satisfactorily for various tree species within and around London, UK. This led to the development of a set of recommendations for planting trees close to structures - in the form of an index chart that is designed for the use of members of the general public. Given its robustness, the systems have scope for broad application elsewhere.

\section{Acknowledgements}

This paper is published with the permission of the Head of the Geotechnical Engineering Office and the Director of Civil Engineering and Development, the Government of the Hong Kong Special Administrative Region, who provided financial support to the first author during her studies at Imperial College London. 


\section{Appendix 1}

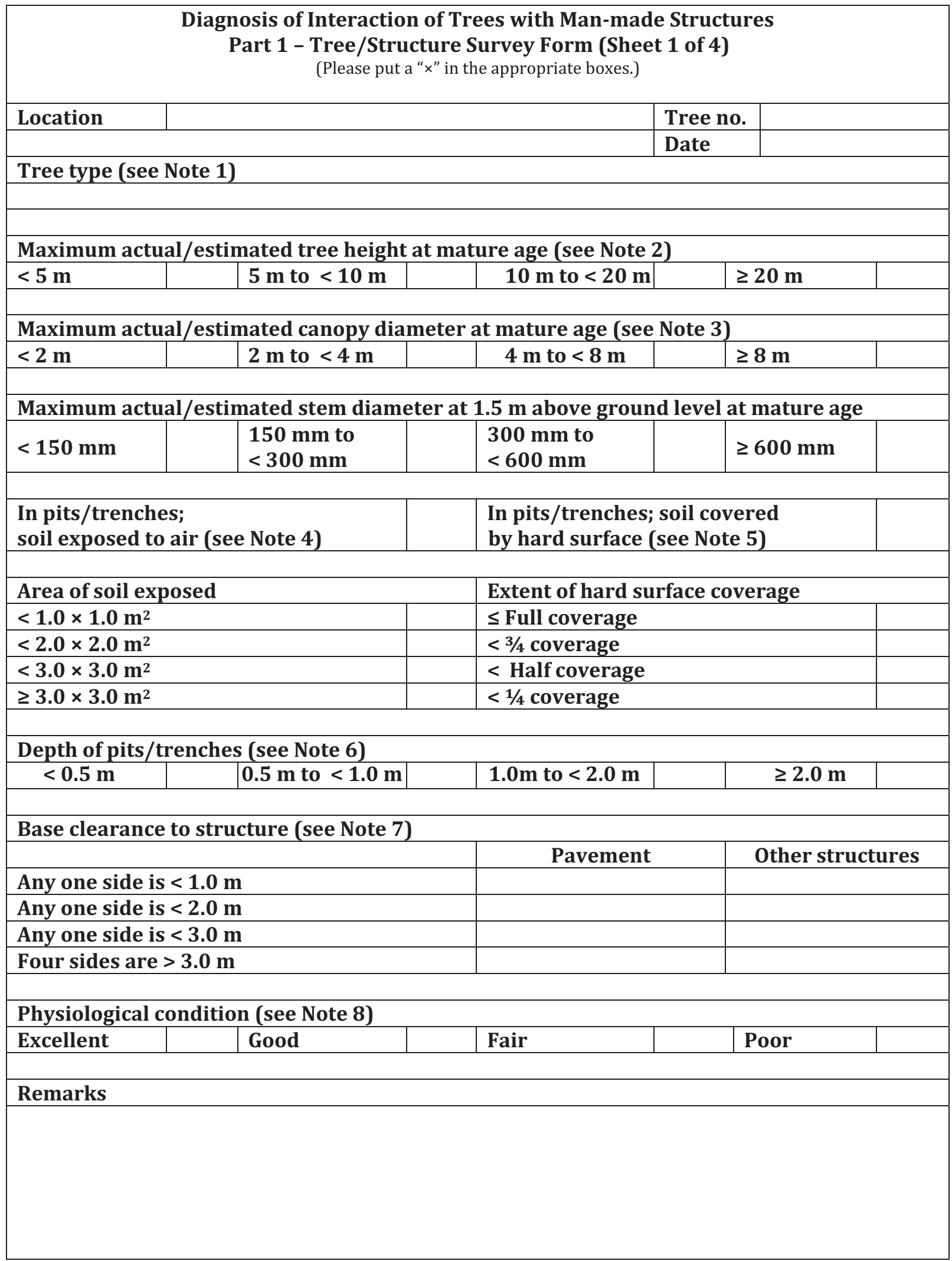


Diagnosis of Interaction of Trees with Man-made Structures

Part 1 - Tree/Structure Survey Form (Sheet 2 of 4)

\section{Sketch/ photograph record}




\section{Diagnosis of Interaction of Trees with Man-made Structures Part 1 - Tree/Structure Survey Form (Sheet 3 of 4)}

Notes:

(1) This item is optional.

(2) This should be the maximum height of crown clearance above existing ground level as shown by the green measurement line in Figure S1.

Figure S1

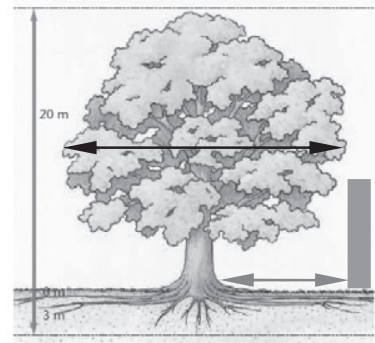

(3) This should be the maximum lateral spread of branches as shown by the red measurement line in Figure S1.

(4) This refers to the tree planting condition as shown in Figure S2 or otherwise similar. If the extent of the exposed soil is not in the shape of a square, an equivalent length of a square may be considered. For example, if the extent of the exposed soil is circular in shape which has a diameter of $2 \mathrm{~m}$, the area is $3.14 \mathrm{~m}^{2}$. The equivalent length of a square is $1.77 \mathrm{~m}$. A ' $x$ ' should therefore be put in the box next to ' $\leq 2.0 \times 2.0 \mathrm{~m}^{2}$ '.

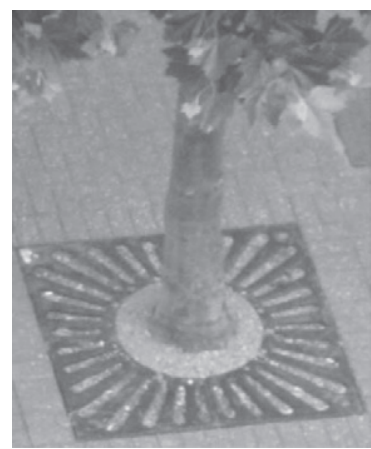

(5) This refers to the tree planting condition as shown in Figure S3 or otherwise similar.

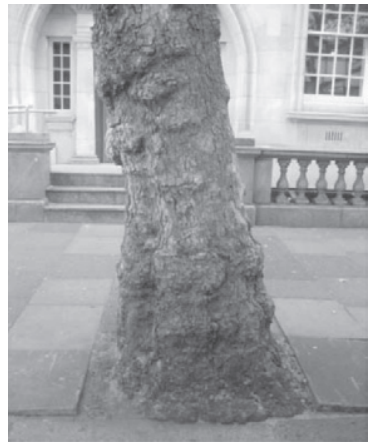

(6) This may not be obvious for existing trees that have already been planted below ground. Judgment should be made based on circumstantial evidence.

(7) This should be the clearance between the base of the tree trunk and the outer boundary of man-made structure as shown by the blue measurement line in Figure S1. If trees are planted in pits, this may be taken as the clearance between the bottom of a tree trunk and the outer boundary of the pit. 


\section{Diagnosis of Interaction of Trees with Man-made Structures}

Part 1 - Tree/Structure Survey Form (Sheet 4 of 4)

(8) The following figures provide a reference to the classification of physiological condition:

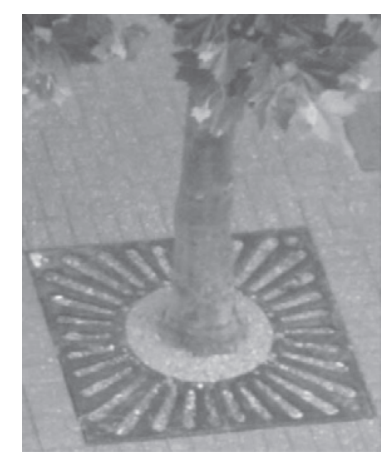

Excellent

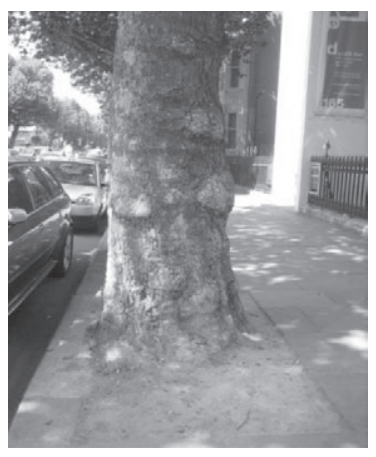

Good

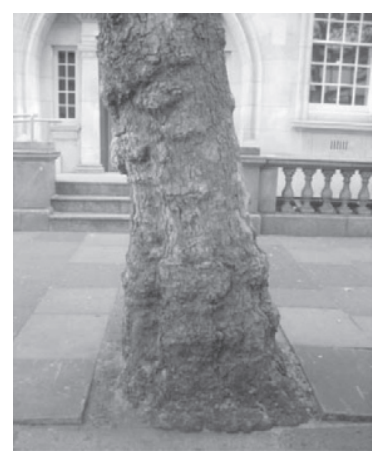

Fair

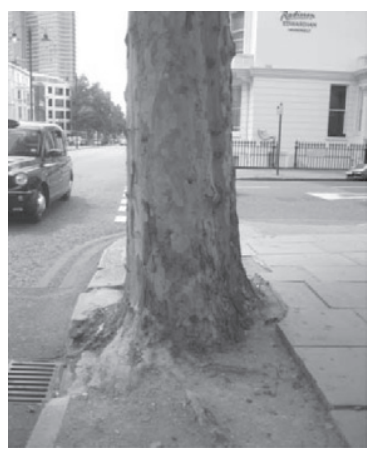

Poor 
(A) Tree groups

\begin{tabular}{|c|c|c|c|c|c|}
\hline & \multicolumn{4}{|c|}{ Maximum actual/estimated stem diameter } \\
\hline & & $<150 \mathrm{~mm}$ & $\begin{array}{l}150 \mathrm{~mm} \text { to } \\
<300 \mathrm{~mm}\end{array}$ & $\begin{array}{l}300 \mathrm{~mm} \text { to } \\
<600 \mathrm{~mm}\end{array}$ & $\geq 600 \mathrm{~mm}$ \\
\hline \multirow{4}{*}{$\begin{array}{l}\text { Maximum } \\
\text { actual/estimated } \\
\text { canopy diameter }\end{array}$} & $<2 \mathrm{~m}$ & G1 & G1 & G2 & G2 \\
\hline & $2 \mathrm{~m}$ to $<4 \mathrm{~m}$ & G1 & G2 & G2 & G3 \\
\hline & $4 \mathrm{~m}$ to $<8 \mathrm{~m}$ & G2 & G2 & G3 & G3 \\
\hline & $\geq 8 \mathrm{~m}$ & G2 & G3 & G3 & G4 \\
\hline
\end{tabular}

(B) Determination of exposure factor, $E_{\mathrm{H}}$

(i) In pits/trenches, with soil exposed to air

\begin{tabular}{|c|c|c|c|c|c|}
\hline & \multicolumn{4}{|c|}{ Area of soil exposed } \\
\hline & & $<1.0 \times 1.0 \mathrm{~m}^{2}$ & $<2.0 \times 2.0 \mathrm{~m}^{2}$ & $<3.0 \times 3.0 \mathrm{~m}^{2}$ & $\geq 3.0 \times 3.0 \mathrm{~m}^{2}$ \\
\hline \multirow{4}{*}{ Tree group } & G1 & 1 & 1 & 1 & 1 \\
\hline & G2 & 3 & 1 & 1 & 1 \\
\hline & G3 & 6 & 3 & 1 & 1 \\
\hline & G4 & 10 & 6 & 3 & 1 \\
\hline
\end{tabular}

(ii) In pits/trenches, with soil covered by hard surface

\begin{tabular}{|c|c|c|c|c|c|}
\cline { 3 - 6 } \multicolumn{2}{c|}{} & \multicolumn{5}{c|}{ Extent of hard surface coverage } \\
\cline { 3 - 6 } \multicolumn{1}{c|}{} & S Full coverage & $<$ 3/4 coverage & $<$ Half coverage & $<\mathbf{1}$ /4 coverage \\
\hline \multirow{3}{*}{ Tree group } & G1 & 10 & 10 & 6 & 3 \\
\cline { 2 - 6 } & G2 & 10 & 10 & 6 & 6 \\
\cline { 2 - 6 } & G3 & 10 & 10 & 10 & 6 \\
\cline { 2 - 6 } & G4 & 10 & 10 & 10 & 6 \\
\hline
\end{tabular}

(C) Determination of depth factor, $D_{\mathrm{H}}$

\begin{tabular}{|c|c|c|c|c|c|}
\cline { 3 - 6 } \multicolumn{2}{c|}{} & \multicolumn{4}{|c|}{ Depth of pits/trenches } \\
\cline { 3 - 6 } \multicolumn{1}{c|}{} & G1 & $<\mathbf{0 . 5} \mathbf{~ m}$ & $\mathbf{0 . 5} \mathbf{~ m}$ to $<\mathbf{1 . 0} \mathbf{~ m}$ & $\mathbf{1 . 0} \mathbf{m}$ to $<\mathbf{2 . 0} \mathbf{~ m}$ & $\geq \mathbf{2 . 0} \mathbf{~ m}$ \\
\cline { 2 - 6 } Tree group & G2 & 6 & 3 & 1 & 1 \\
\cline { 2 - 6 } & G3 & 10 & 3 & 1 & 1 \\
\cline { 2 - 6 } & G4 & 10 & 6 & 3 & 1 \\
\hline
\end{tabular}




\begin{tabular}{|c|c|c|c|}
\hline \multicolumn{4}{|c|}{$\begin{array}{l}\text { Diagnosis of Interaction of Trees with Man-made Structures } \\
\text { Part } 2 \text { - Tree/Structure Risk Assessment Form (Sheet } 2 \text { of 3) }\end{array}$} \\
\hline \multicolumn{4}{|c|}{ (D) Determination of structural factor, $S_{\mathrm{C}}$} \\
\hline \multirow{4}{*}{ Structures } & \multirow{2}{*}{ Without lateral restraint } & $\begin{array}{l}\text { Very light (e.g. asphalt/brick } \\
\text { pavement or low brick wall) }\end{array}$ & 10 \\
\hline & & Light (e.g. high brick wall) & 6 \\
\hline & \multirow{2}{*}{ With lateral restraint } & $\begin{array}{c}\text { Substantial } \\
\text { (e.g. concrete parapet wall) }\end{array}$ & 3 \\
\hline & & $\begin{array}{c}\text { Very substantial } \\
\text { (e.g. concrete building wall) }\end{array}$ & 1 \\
\hline
\end{tabular}

(E) Determination of proximity factor, $P_{\mathrm{C}}$

\begin{tabular}{|c|c|c|c|c|c|}
\cline { 3 - 6 } \multicolumn{2}{c|}{} & \multicolumn{4}{c|}{ Base clearance } \\
\cline { 3 - 6 } \multicolumn{2}{c|}{} & $\begin{array}{c}\text { Any one side is } \\
<\mathbf{1 . 0} \mathbf{m}\end{array}$ & $\begin{array}{c}\text { Any one side is } \\
<2.0 \mathrm{~m}\end{array}$ & $\begin{array}{c}\text { Any one side is } \\
<3.0 \mathrm{~m}\end{array}$ & $\begin{array}{c}\text { Four sides are } \\
>3.0 \mathrm{~m}\end{array}$ \\
\hline \multirow{3}{*}{ Tree group } & G1 & 3 & 1 & 1 & 1 \\
\cline { 2 - 6 } & G2 & 6 & 3 & 1 & 1 \\
\cline { 2 - 6 } & G3 & 10 & 6 & 3 & 1 \\
\cline { 2 - 6 } & G4 & 10 & 6 & 3 & 1 \\
\hline
\end{tabular}

(F) Calculation of risk score, $R_{1}$

Risk score $=($ Exposure factor + Depth factor $)+($ Structural factor + Proximity factor $)$

$R_{1}=H_{1}+C_{1}=\left(E_{\mathrm{H}}+D_{\mathrm{H}}\right)+\left(S_{\mathrm{C}}+P_{\mathrm{C}}\right)$

For pavement:

\begin{tabular}{|l|l|}
\hline Exposure factor & \\
\hline Depth factor & \\
\hline Structural factor & \\
\hline Proximity factor & \\
\hline Risk score & \\
\hline
\end{tabular}

For other structures:

\begin{tabular}{|l|l|}
\hline Exposure factor & \\
\hline Depth factor & \\
\hline Structural factor & \\
\hline Proximity factor & \\
\hline Risk score & \\
\hline
\end{tabular}




\section{Diagnosis of Interaction of Trees with Man-made Structures Part 2 - Tree/Structure Risk Assessment Form (Sheet 3 of 3)}

(G) Evaluation of risk score, $R_{1}$

\begin{tabular}{|l|l|l|l|}
\hline Risk score & Risk classification & Description \\
\hline$<10$ & Very unlikely & & $\begin{array}{l}\text { Adverse interaction of trees with man-made structures is } \\
\text { very unlikely. }\end{array}$ \\
\hline 10 to $<20$ & Unlikely & & $\begin{array}{l}\text { Adverse interaction of trees with man-made structures is } \\
\text { unlikely. }\end{array}$ \\
\hline 20 to $<30$ & Likely & $\begin{array}{l}\text { Adverse interaction of trees with man-made structures is } \\
\text { likely. }\end{array}$ \\
\hline 30 to 40 & Very likely & $\begin{array}{l}\text { Adverse interaction of trees with man-made structures is } \\
\text { very likely. }\end{array}$ \\
\hline
\end{tabular}

(H) Remarks 


\section{Appendix 2}

\section{Diagnosis of Interaction of Trees with Man-made Structures Part 2 - Tree/Structure Risk Assessment Form (Sheet 1 of 2)}

(A) Determination of species factor, $S_{\mathrm{H}}$

\begin{tabular}{|l|l|c|}
\hline \multirow{4}{*}{$\begin{array}{l}\text { Tree } \\
\text { species }\end{array}$} & $\begin{array}{l}\text { Apple, Pear, Ash, Beech, Birch, Cherry, Plum, Damson, } \\
\text { etc., Elm, False acacia, Hawthorn, Horse chestnut, Lime, }\end{array}$ & 1 \\
& $\begin{array}{l}\text { Oak, Plane, Poplar, Rowan, Service tree, White beam, } \\
\text { Sycamore, Maple, Willow }\end{array}$ & \\
\cline { 2 - 3 } & Other species & 0 \\
\hline
\end{tabular}

(B) Determination of structural factor, $S_{\mathrm{C}}$

\begin{tabular}{|l|c|c|c|}
\hline \multirow{5}{*}{ Structures } & \multirow{2}{*}{ Without lateral restraint } & $\begin{array}{c}\text { Very light } \\
\text { (e.g. asphalt/brick } \\
\text { pavement or low brick wall) }\end{array}$ & 10 \\
\cline { 3 - 4 } & \multirow{2}{*}{ With lateral restraint } & Light (e.g. high brick wall) & 6 \\
\cline { 3 - 4 } & & $\begin{array}{c}\text { Substantial } \\
\text { (e.g. concrete parapet wall) }\end{array}$ & 3 \\
\cline { 3 - 4 } & $\begin{array}{c}\text { Very substantial } \\
\text { (e.g. concrete building wall) }\end{array}$ & 1 \\
\hline
\end{tabular}

(C) Determination of combined height-proximity factor, $H P_{\mathrm{HC}}$

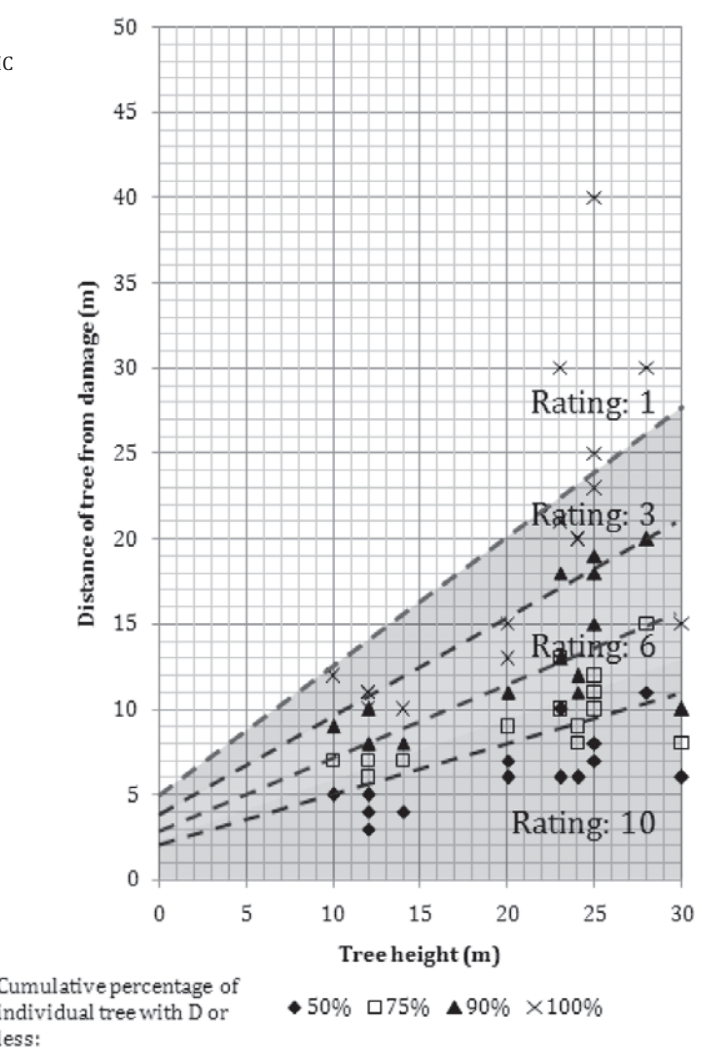




\section{Diagnosis of Interaction of Trees with Man-made Structures \\ Part 2 - Tree/Structure Risk Assessment Form (Sheet 2 of 2)}

(D) Calculation of risk score, $R_{2}$

Risk score $=$ Species factor $\times$ (Structural factor + Combined height-proximity factor $)$

$R_{2}=S_{\mathrm{H}} \times\left(S_{\mathrm{c}}+\mathrm{HP}_{\mathrm{HC}}\right)$

\begin{tabular}{|l|l|}
\hline Species factor, $S_{\mathrm{H}}$ & \\
\hline Structural factor, $\boldsymbol{S}_{\mathrm{C}}$ & \\
\hline Combined height-proximity factor, $H P_{\mathrm{HC}}$ & \\
\hline Risk score, $\boldsymbol{R}_{2}$ & \\
\hline
\end{tabular}

(E) Evaluation of risk score

\begin{tabular}{|l|l|l|l|}
\hline Risk score & Risk classification & Description \\
\hline$<5$ & $\begin{array}{l}\text { Very } \\
\text { unlikely }\end{array}$ & $\begin{array}{l}\text { Adverse interaction of trees with man-made structures } \\
\text { is very unlikely. }\end{array}$ \\
\hline 5 to $<10$ & Unlikely & $\begin{array}{l}\text { Adverse interaction of trees with man-made structures } \\
\text { is unlikely. }\end{array}$ \\
\hline 10 to $<15$ & Likely & $\begin{array}{l}\text { Adverse interaction of trees with man-made structures } \\
\text { is likely. }\end{array}$ \\
\hline 15 to 20 & Very likely & $\begin{array}{l}\text { Adverse interaction of trees with man-made structures } \\
\text { is very likely. }\end{array}$ \\
\hline
\end{tabular}

(F) Remarks 


\section{REFERENCES}

Biddle PG (1998) Tree Root Damage to Buildings. Willowmead Publishing Ltd, Oxford, UK, vols. 1 and 2.

BRE (Building Research Establishment) (1990, rev 1995) Assessment of Damage in Low-Rise Buildings, with Particular Reference to Progressive Foundation Movement, BRE, Garston, UK, Digest 251.

BSI (2005) BS 5837:2005: Trees in relation to constructionrecommendations. British Standards Institution, London, UK.

Burland JB (1995) Assessment of risk of damage to buildings due to tunnelling and excavations. Invited special lecture. In Proceedings of 1st International Conference on Earthquake Geotechnical Engineering, IS-Tokyo' 95, Japan (Ishihara K (eds)). A. A. Balkema, Rotterdam, Tokyo, Japan, pp. 1189-1201.

Costello LR and Jones KS (2003) Reducing Infrastructure Damage by Tree Roots: A Compendium of Strategies. Western Chapter of the International Society of Arboriculture, Champaign, IL, USA.

Cutler DF and Richardson IBK (1989) Tree Roots and Buildings. Longman Scientific \& Technical, Essex, UK.
NHBC (National House-Building Council) (2008)

NHBC Standards. National House-Building Council, Milton Keynes, UK, Chapter 4.2.

NJUG (National Joint Utilities Group) (2007) Guidelines for the Planning, Installation and Maintenance of Utility Apparatus in Proximity to Trees.

National Joint Utilities Group, London, UK, vol. 4, Issue 2

ODPM (Office of the Deputy Prime Minister) (2005) Hedge Height and Light Loss. Office of the Deputy Prime Minister Planning, London, UK.

OPSI (Office of Public Sector Information) (1967) The Forestry Act 1967 (As Amended). Office of Public Sector Information, London, UK.

OPSI (1990) The Town and Country Planning Act 1990 (As Amended). Office of Public Sector Information, London, UK.

OPSI (1994) The Conservation (Natural Habitats etc.) Regulations 1994. Office of Public Sector Information, London, UK.

OPSI (2000) Building Regulations 2000. Office of Public Sector Information, London, UK.

\section{HOW CAN YOU CONTRIBUTE?}

To discuss this paper, please email up to 500 words to the editor at journals@ice.org.uk. Your contribution will be forwarded to the author(s) for a reply and, if considered appropriate by the editorial board, it will be published as discussion in a future issue of the journal.

Proceedings journals rely entirely on contributions from the civil engineering profession (and allied disciplines). Information about how to submit your paper online is available at www.icevirtuallibrary.com/page/authors, where you will also find detailed author guidelines. 